\title{
O BEM DE FAMÍLIA COMO PROTEÇÃO MÍNIMA À MORADIA
}

\author{
Luiz Henrique Machado Cordeiro*
}

Introdução. 1. O bem de família no Código Civil de 2002, em perspectiva com sua evolução histórica. 2. A Lei $\mathrm{n}^{\circ} 8.009 / 90$ e sua aplicação em face do ordenamento jurídico atual. 3. Principais temas controvertidos em jurisprudência. Conclusão. Referências Bibliográficas.

\section{RESUMO:}

Este estudo se ocupa do instituto jurídico do bem de família enquanto proteção mínima prevista em lei, na dimensão patrimonial, às entidades familiares. Partindo de sua origem, será apresentada a sua evolução no direito brasileiro, ressaltando-se sua importância e aplicabilidade. Considerando sua posição singular, na confluência do direito de família (garantia de moradia) com o direito das coisas (restrição ao direito de propriedade), a abordagem desse importante instituto jurídico será vista à luz dos vários textos legais que lhe deram vida. Analisando o bem de família voluntário, previsto no Código Civil de 2002, e o bem de família legal, previsto pela Lei $\mathbf{n}^{\circ}$ $8.009 / 90$, serão destacadas as suas principais diferenças e semelhanças, à luz do princípio constitucional norteador da blindagem do patrimônio familiar. Por fim, serão apresentadas as controvérsias mais recorrentes em jurisprudência. Pretende-se com este trabalho apresentar um panorama claro e ao mesmo tempo conciso sobre o bem de família no direito brasileiro, haja vista a sua relevância e os perigos que a sua não compreensão podem gerar, com gravíssimos prejuízos à

\footnotetext{
* Mestrando em Direito pela UFRGS. Especialista em Direito Empresarial pela UFRGS. Especialização pela ESMP. Advogado com atuação na área do Direito Privado.
} 
célula a partir da qual a sociedade se estrutura.

\section{Palavras- chave:}

Bem - família - proteção - moradia

\section{INTRODUÇÃO}

Existe certo consenso de que o Direito Romano não conheceu o instituto do bem de família. Sua origem, e quanto a isso não se vê controvérsia, é encontrada no Homestead Expedition Act ${ }^{1}$, de 26/01/1938, da então República do Texas, à época ainda não incorporada aos Estados Unidos, o que só ocorreu em $1845^{2}$, tendo como objeto, inicialmente, a pequena propriedade residencial agrícola familiar $^{3}$, conferindo proteção especial ao domicílio da família do agricultor contra crises econômicas. No direito norte-americano, recebeu a denominação homestead por significar o local onde a família assenta o seu lar, a sua casa: home (sua casa) e stead (lugar), embora existam vozes discordantes, conforme assinala ESPÍNOLA. ${ }^{4}$

No direito brasileiro, o tema em questão está situado em uma área de confluência entre o Direito de Família e o Direito das Coisas, propiciando relevantes discussões que, todavia, desbordam o Direito Privado, à medida que a proteção familiar de natureza patrimonial prevista na Lei $\mathrm{n}^{\circ}$ 8.009/90 decorre de uma imposição do Estado, em prol do direito à moradia do núcleo familiar, materializando na legislação ordinária a garantia fundamental encartada na Constituição da República. ${ }^{5}$

1 MARMITT, Arnaldo. Bem de familia. Rio de Janeiro: Aide, 1995, p.16.

2 AZEVEDO, Álvaro Vilaça. Bem de Familia. $2^{\text {a }}$ edição. São Paulo: Editora Revista dos Tribunais, 1984, p. 11.

3 RITONDO, Domingo Pietrangelo. Bem de família. Rio de Janeiro: Elsevier, 2008, p. 19 .

4 ESPINOLA,Eduardo. Breves Annotações ao Código Civil Brasileiro. Volume Primeiro. Bahia: Joaquim Ribeiro \& Co Editores. 1918, p. 172/173: "Em todas as discussões em torno do homestead, ou bem de família, se tem procurado salientar a origem americana do instituto e a excellencia de suas virtudes. Ha, porem, vozes dissonantes, que se não limitam a accentuar-lhes os inconvenientes, mas lhes desconhecem as vantagens no próprio Estado que, por primeiro, o adaptou" (ipsis literis).

5 Artigo 60. São direitos sociais a educação, a saúde, o trabalho, a moradia, o lazer, a segurança, a previdência social, a proteção à maternidade e à infância, a assistência aos desamparados, na forma desta Constituição (Redação dada pela Emenda Constitucional $\mathrm{n}^{\circ} 26$, de 2000). 
A propósito, calha observar que será analisado no decorrer deste trabalho o duplo tratamento legislativo que esse tipo de proteção familiar desfruta atualmente. Por um lado, na forma definida pela Lei $\mathrm{n}^{\circ} 8.009 / 90$, com sua proteção de natureza pública, instituída verticalmente pelo Estado e, de outro, conforme os ditames do Código Civil de 2002, que disciplina o bem de família voluntário, ou convencional, instituído pela vontade privada, mediante escritura pública ou testamento, e que deve ser devidamente registrado no Cartório de Registro de Imóveis para ganhar eficácia erga omnes.

Ressalvadas as exceções constantes do Artigo 1.715, que abrange as dívidas anteriores à instituição, as dívidas posteriores de tributos incidentes sobre o próprio imóvel e as dívidas posteriores de condomínio, o Código Civil, além de proteger o bem de família pela impenhorabilidade, ainda prevê a possibilidade de sua inalienabilidade (Artigo 1.717).

Ver-se-ão ao longo deste estudo algumas questões controvertidas que envolvem atualmente $o$ instituto, uma delas acerca da proteção da impenhorabilidade do imóvel no qual reside pessoa solteira, questão que o Superior Tribunal de Justiça consolidou o seu entendimento.

Outra questão relevante é o entendimento, em doutrina e em jurisprudência, a respeito da amplitude do conceito de família para efeito de proteção pela impenhorabilidade conferida em nível infraconstitucional, tendo em vista as entidades familiares, restritivamente previstas no Artigo 226 da Constituição da República (uniões estáveis e entidades monoparentais), que nada referiu às uniões homoafetivas.

Como ponto de discussão, ressalta-se também a polêmica que os Tribunais e operadores do direito vêm enfrentando com o denominado: "bem de família ofertado", onde o bem de família é oferecido à penhora pelo próprio devedor.

Várias são as polêmicas relativas ao bem de família, que através do presente estudo, sem a pretensão de esgotar a matéria, serão analisadas, com o exame de alguns casos considerados de alta relevância. $O$ estudo se debruçará sobre aspectos jurídi$\cos$, doutrinários e jurisprudenciais, contribuindo assim para sua melhor compreensão, pois se trata de instituto diretamente relacionado com uma das necessidades fundamentais do ser humano, qual seja, o tão propalado direito de moradia como corolário da dignidade humana.

\section{O BEM DE FAMÍLIA NO CÓDIGO CIVIL DE 2002, EM PERSPECTIVA COM A SUA EVOLUÇÃO HISTÓRICA}

No Brasil, a introdução do instituto no ordenamento jurídico 
se deu com os artigos 70 a 73 do Código Civil de 1916, passando pelo Decreto-Lei $\mathrm{n}^{\circ}$ 3.200, de 19.04.1941 (artigos 19 a 23), que dispôs sobre a organização e proteção da família, estabelecendo incentivos para o seu desenvolvimento. Na sequência, a Lei $\mathrm{n}^{0}$ 6.015, de 31.12.1973, regrou aspectos formais da instituição do bem de família junto ao Registro de Imóveis. $\mathrm{Na}$ década de 80 , a Constituição da República de 1988, que introduziu uma nova visão dos direitos sociais, influenciando a legislação infraconstitucional que estava por vir.

Com base na nova visão social da Magna Carta, foi concebida a Lei $n^{\circ} 8.009$, de 29.03.1990, em que pese o direito à moradia só viesse a ter expresso status de garantia constitucional com o advento da Emenda Constitucional 26, do ano de 2000 , que deu nova redação ao caput do Art. $6^{\circ}$ da Constituição da República.

Por fim, o instituto do bem de família recebeu novos contornos, dados pelas disposições plasmadas no Código Civil de 2002 (artigos 1.711 a 1.722).

A localização topográfica do instituto no Código Civil de 1916 e, depois, no Código Civil de 2002, bem demonstra que passado quase um século (86 anos) não apenas o instituto sofreu modificações, mas a sua visão pelo legislador mudou de ângulo. No Código Civil de 1916 era disciplinado na Parte Geral, no Livro reservado aos Bens ${ }^{6}$ (não no Livro do Direito de Família), ao passo que no Código Civil de 2002 foi regrado na Parte Especial, no Livro do Direito de Família. Tal circunstância decorre do fato de que a sociedade recém-saída do Século 19 ainda era extremamente patriarcal ${ }^{7}$ (Artigo $70-E$ permitido ao chefe de familia destinar...), individualista, à medida que o indivíduo era o elemento norteador da ordem jurídica, com sua economia centrada na riqueza imobiliária, ao passo que a sociedade que concebeu o Código Civil de 2002 vivia sob os auspícios da Constituição de 1988, de cunho social.

6 ESPINOLA, Eduardo. Breves Annotações ao Código Civil Brasileiro. Volume Primeiro. Bahia: Joaquim Ribeiro \& Co Editores, 1918, p. 172, assinala que, no projeto do Código Civil de 1916, o instituto do bem de família fora colocado no livro primeiro (Das pessoas) e, somente depois de muitas críticas, em especial de Justiniano de Serpa, é que a Comissão do Senado, presidida por Feliciano Penna, em 1912, deslocou os artigos referentes ao bem de família para o livro segundo (Dos Bens).

7 Código Civil de 1916 - Artigo 70. É permitido aos chefes de família destinar um prédio para domicílio desta, com a cláusula de ficar isento de execução por dívidas, salvo as que provierem de impostos relativos ao mesmo prédio. 
O deslocamento do instituto jurídico do "Bem de Família" da disciplina reservada aos Bens (1916), para a disciplina do Direito de Família (2002), demonstra o ângulo de visão da sociedade em relação à proteção pretendida e, o mais importante, a hierarquia dos valores sociais vigentes em cada época. No diploma legal de 1916 a proteção era uma prerrogativa exclusiva e pessoal do chefe de família ("chefe", líder e todo poderoso), ao passo que no diploma legal de 2002 tal proteção pode ser instituída por ambos os cônjuges e também pela "entidade familiar". A legislação atual sequer restringe o benefício à "família" no sentido conservador do termo, reservado àquela decorrente do casamento, ampliando sua aplicação ao que denomina de "entidade familiar". Retirou-se o poder exclusivo do "chefe" e alargou-se o espectro dos beneficiados.

$\mathrm{O}$ arrefecimento do caráter disponivvel para a instituição da proteção familiar em estudo, que, no Código Civil de 1916, dependia exclusivamente do querer do chefe de família, se fez sentir em 1990, ou seja, antes mesmo da vigência do Código que o sucedeu. A Lei $n^{\circ} 8.009 / 90$, forjada em sintonia com os princípios e valores encartados na Constituição da República (promulgada dois anos antes) ${ }^{8}$, instituiu a proteção do bem de família de forma geral e impositiva, portanto, não mais dependendo do querer do chefe familiar (vontade individual), mas em decorrência da vontade do Estado, como desdobramento de uma política pública que visa a promoção da proteção da família em sentido amplo.

Em síntese bastante apertada, pode se dizer que o bem de família no direito pátrio é um meio eficaz para garantir ao núcleo familiar um reduto inviolável, guardando estreita ligação com sua origem no homestead", pondo-o a salvo das investidas dos credores(impenhorável)e dos próprios beneficiados (inalienabilidade), revelando a superioridade do interesse tutelado em relação aos demais, que eventualmente com ele conflitam (interesses econômicos, patrimoniais, privados e públicos), ressalvadas as exceções previstas em lei.

Como se pode ver, a residência familiar enquanto propriedade, e

8 Embora a Emenda Constitucional 26, que guindou o direito à moradia à condição de direito social fundamental tenha sido introduzida dez anos depois, em 2000, não significa dizer que a Lei 8.009/90 se ressinta desse espírito em sua gênese. A Emenda Constitucional 26 apenas fez explicitar o que já se achava implícito na Constituição da República, assim como, posteriormente, o fez a Emenda Constitucional 64, de 2010, em relação à "alimentação".

9 AZEVEDO, Álvaro Vilaça; op. cit., p. 76. 
a moradia enquanto direito social (constitucionalmente garantido) são conceitos que convergem para uma mesma finalidade, qual seja, dar proteção ao núcleo familiar, célula-mãe da sociedade, algo, aliás, reconhecido em praticamente todos os sistemas jurídicos civilizados, conforme observação de Álvaro -Villaça Azevedo, em importante estudo desse instituto jurídico sob a égide do Código Civil anterior.

Considerando que o bem de família representa uma proteção, e que toda proteção implica alguma restrição, não tarda notar que a restrição se dá sob dois frontes; de um lado em relação aos direitos e interesses de terceiros, por outro, em relação aos direitos e interesses do(s) proprietário(s) do bem sobre o qual recai o manto legal protetivo. Neste ponto, o Direito de Família se comunica fortemente com o Direito das Coisas, no que tange ao direito de propriedade. No caput do Artigo 1.228 do Código Civill, ${ }^{10}$ destacam-se os atributos do direito de propriedade, dentre os quais está o poder do proprietário de dispor da coisa (jus disponendi). Com efeito, quando a restrição parte do próprio titular do direito de propriedade (autorrestrição), tem-se o bem de família voluntário, porquanto, a restrição ao seu direito de disponibilidade decorre da sua vontade individual.

Essa questão não passou despercebida da doutrina: "Devese observar que o bem de família envolve direitos, não se confundindo com o imóvel residencial sobre o qual eventualmente incide. Esse conjunto de direitos, ao recair sobre determinada residência, transformase em qualidade dela. Além de ser atributo o que se agrega ao imóvel residencial da entidade familiar, o bem de família representa ainda uma restrição ao direito de propriedade, uma vez que o titular do bem perde boa parte do poder de dispor do seu domínio, passando a possuir um imóvel relativamente inalienável." $" 11$

Pela atualidade que encerra, a análise da legislação brasileira, neste tópico, ficará mais centrada no Código Civil de 2002, com breves cotejos de suas disposições

10 C.C. 2002. Artigo 1.228. "O proprietário tem a faculdade de usar, gozar e dispor da coisa, e o direito de reavê-la do poder de quem quer que injustamente a possua ou detenha."

11 RITONDO, apud CREDIE, Ricardo Arcoverde. Bem de familia: teoria e prática. São Paulo: Saraiva, 2004, p. 5-6. 
com as de outros diplomas legais. O Código Civil em vigor trouxe pontuais inovações, promovendo uma reformulação no instituto do bem de família, adaptando-se às exigências do texto constitucional, decorrentes do princípio da dignidade humana, bem como da igualdade entre os cônjuges e companheiros e das diversas formas de modelos familiares. Conforme salienta RITONDO, hoje pode-se definir o bem de família como o direito de isenção relativa à apreensão judicial, que se estabelece por força de lei ou por manifestação de vontade, sobre o imóvel urbano ou rural, de domínio integrante da entidade familiar, residência efetiva desta, que alcança ainda os bens móveis quitados que guarneçam, ou somente esses, caso o prédio que não seja próprio, além das pertenças e alfaias, e eventuais valores mobiliários afetados de suas rendas..$^{12}$

A primeira e grande alteração introduzida refere-se à ampliação da legitimidade para a constituição do bem de família. Veja-se que o Artigo 1.711 do Código Civil em vigor estabelece que podem os cônjuges, ou a entidade familiar, mediante escritura pública ou testamento, destinar parte de seu patrimônio para instituir bem de família, desde que não ultrapasse um terço do patrimônio líquido existente ao tempo da instituição, mantidas as regras sobre a impe-nhorabilidade do imóvel residencial estabelecida em lei especial.

Dúvidas se formaram com a extensão do significado da expressão "entidade familiar", com o disposto no parágrafo $4^{\circ}$ do Artigo $226 \mathrm{da} \mathrm{CF}$ : "Entende-se como entidade familiar a comunidade formada por qualquer dos pais e seus descendentes".

Nesse sentido, VELOSO, esclarece a entidade familiar, para instituição do bem de família: "O bem de família é um instituto de proteção que pode ser utilizado pelas famílias matrimonializadas, pelas famílias constituídas pela união estável e pelas famílias monoparentais, e, embora o Código Civil não tenha dito isso com a necessária clareza, é uma conclusão inarredável e imposta por uma interpretação conforme a constituição" ${ }^{13}$

Ocorre que as mudanças na configuração da família decorrem de uma evolução da sociedade e, nesse contexto, o conceito restrito de família que antes só significava a

12 RITONDO, apud, CREDIE, op. cit. p. 24.

13 RITONDO, apud, VELOSO, Zeno. Código Civil Comentado, V.XVII, Álvaro Villaça Azevedo (coord.). São Paulo: Atlas, 2003, p.74. 
família constituída pelo casamento, veio perdendo terreno com os passar dos tempos e, dando espaço às chamadas entidades familiares, dentre as quais a família "monoparental" e a impropriamente denominada família "unipessoal".

Além disso, observa-se hoje uma grande ocorrência de diversos grupos familiares formados das maneiras mais variadas, tais como parentes que habitam a mesma casa (p. ex.: os irmãos, a avó com o neto, dentre tantas outras situações), as uniões estáveis, casais sem filhos e as próprias uniões homoafetivas. Além do mais, a jurisprudência já tem acolhido em grande parte a tese de uma interpretação mais ampliativa da família. ${ }^{14,15}$

Ainda com relação ao Artigo 1.711, há a previsão expressa da

14 CIVIL E PROCESSUAL CIVIIL. EXECUÇÃO. IMÓVEL RESIDENCIAL. IMPENHORABILIDADE. LEI 8.009/90. ENTIDADE FAMILIAR. DEVEDOR DIVORCIADO. IMÓVEL HABITADO PELA EX-MULHER E PELA FILHA.

I - O conceito de entidade familiar deve ser compreendido de acordo com as alterações que se processaram nos últimos tempos no Direito de Família, de modo a ser preservado o sentido social da Lei 8.009/90. II - Não se expõe à penhora o imóvel de propriedade do executado e de sua ex-esposa, quando se destina à moradia desta última e da filha, vez que a proteção da Lei 8.009/90 atinge o bem por inteiro e não apenas a meação da mulher, sob pena de prejudicar o núcleo familiar. Recurso especial provido. Terceira Turma, Resp.239.291 - SP, Rel. Min. Castro Filho, julgado em 6\09\2002.

Disponível em:<https://ww2.stj.jus.br/websecstj/cgi/revista/REJ>. Acesso em: 05.01.2011. 15 EXECUÇÃO. EMBARGOS DE TERCEIRO. IMPENHORABILIDADE. IMÓVEL RESIDENCIAL DA FAMÍLIA. CERCEAMENTO DE DEFESA. LEGITIMIDADE DE PARTE. IRRETROATIVIDADE DA LEI No $8.009 / 90$. VIÚVA.

- Inocorrência no caso do alegado cerceamento de defesa, adstrita que fora a objeção do Banco embargado ao ônus da embargante de comprovar os requisitos estabelecidos na Lei $\mathrm{n}^{\circ} 8.009 / 90$. "Têm legitimidade a mulher e os filhos para, em embargos de terceiro, defender bem de família sobre o qual recaiu medida coercitiva, mesmo que ela figure juntamente com o marido como executada, vedada tão só a discussão do débito" (REsp $\mathrm{n}^{0}$ 64.021-SP).

- A Lei $n^{\circ} 8.009 / 90$ aplica-se à penhora realizada antes de sua vigência

(Súmula n ${ }^{\circ}$ 205-STJ).

- A viúva, ainda que more só no imóvel residencial, acha-se protegida pela impenhorabilidade prevista na mencionada Lei n ${ }^{\circ} 8.009 / 90$. Recurso especial não conhecido". (Quarta Turma, Resp. 434.856-PR, Rel. Min. Barros Monteiro, julgado em 22\10\2002) Disponível em: < https://ww2.stj.jus.br/revistaeletronica $>$. Acesso em: 05/01/2011. 
possibilidade da constituição do bem de família através do testamento, além da escritura pública, conforme já previa a legislação anterior.

Outra modificação produzida pelo artigo em exame foi a limitação de valor para que se possa constituir o bem de família, que não poderá ultrapassar um terço do patrimônio líquido existente ao tempo da instituição. Consequentemente, quem possui apenas um imóvel não poderá fazer uso dessa instituição, embora a família permaneça protegida pelas disposições da Lei $\mathrm{n}^{\circ}$ 8.009/90, que trata do bem de família legal, que protege o pequeno, o médio e o grande proprietário, indistintamente.

O parágrafo único do Artigo 1.711 dispõe que: "O terceiro poderá igualmente instituir bem de família por testamento ou doação, dependendo a eficácia do ato da aceitação expressa de ambos os cônjuges beneficiados ou da entidade familiar beneficiada". Esse artigo traz uma inovação sobre a legitimação para a constituição de bem de família voluntário, que é a possibilidade de instituição de bem de família por terceiros. Contudo, o artigo dispõe que a instituição se faça por doação ou testamento, e que só haverá eficácia se houver a concordância dos cônjuges ou da entidade familiar. Deve haver, no caso, transferência de propriedade.

O Artigo 1.712, por sua vez, dispõe sobre o objeto do bem de família, ponto no qual o Código Civil inovou bastante.

Historicamente, a noção de bem de família vem sendo ampliada, podendo ser identificados quatro passos na evolução do instituto. $O$ passo inaugural, dado pelo legislador do Código Civil de 1916, restringia-se apenas ao prédio destinado para o domicílio da família. O segundo passo, dado pelo Decreto-Lei $\mathrm{n}^{\circ} 3.200 / 41$, manteve o imóvel de residência como o objetivo principal do instituto, porém com inovação interessante, passando a admitir, exclusivamente em relação ao prédio de zona rural, que a proteção recobrisse também a mobília e utensílios de uso doméstico, gado e instrumentos de trabalho. ${ }^{16} \mathrm{O}$ terceiro veio com a Lei $\mathrm{n}^{\circ} 8.009 / 90$, que,

16 Dec.-Lei n ${ }^{\circ} 3.200 / 41$ - Art. 22. Quando instituído em bem de família prédio de zona rural, poderão ficar incluídos na instituição a mobília e utensílios de uso doméstico, gado e instrumentos de trabalho, mencionados discriminadamente na escritura respectiva. 
valendo-se da noção de domicílio, ${ }^{17}$ manteve-se fiel ao objeto principal do instituto (imóvel residencial para moradia permanente), com a vantagem de haver corrigido a omissão do Decreto-Lei $n^{\circ} 3.200 / 41$ em relação aos "acessórios" vinculados ao imóvel urbano. No parágrafo único ao seu Artigo $1^{\circ}$, aquela lei passou a incluir sob o manto da impenhorabilidade, seja rural ou urbano o imóvel, as plantações, as benfeitorias de qualquer natureza e todos os equipamentos, inclusive os de uso profissional, ou móveis que guarneçam a casa, desde que quitados. O quarto e último passo na evolução do objeto do bem de família no direito pátrio foi dado pelo legislador do Código Civil de 2002, ao estabelecer, no Artigo 1.711, que o instituto pode recair sobre "parte do patrimônio" dos cônjuges ou da entidade familiar (desde que não ultrapasse um terço do patrimônio líquido existente ao tempo da instituição).

Ao estabelecer uma fração sobre todo o acervo patrimonial, o Código Civil atual deixa clara a disposição no sentido de que o objeto principal do instituto foi ampliado. E o Artigo 1.712 confirma essa conclusão, ${ }^{18}$ quando define expressamente dois tipos de bens passíveis de serem protegidos pelo instituto em estudo. $\mathrm{O}$ indicado dispositivo legal estabelece que o bem de família consistirá em (1) prédio residencial destinado ao domicílio familiar e (2) valores mobiliários, cuja renda será aplicada (destinação) na conservação do imóvel e no sustento da família. O primeiro tipo de bem (imobiliário) é o bem de família clássico, tradicional, que remonta à origem do instituto jurídico. O segundo tipo (valores mobiliários), no entanto, encerra grande novidade,

17 Art. $5^{\circ}$ - Para os efeitos de impenhorabilidade, de que trata esta lei, considerase residência um único imóvel utilizado pelo casal ou pela entidade familiar para moradia permanente.

Parágrafo único. Na hipótese de o casal, ou entidade familiar, ser possuidor de vários imóveis utilizados como residência, a impenhorabilidade recairá sobre o de menor valor, salvo se outro tiver sido registrado, para esse fim, no Registro de Imóveis e na forma do art. 70 do Código Civil.

18 Art. 1.712. O bem de família consistirá em prédio residencial urbano ou rural, com suas pertenças e acessórios, destinando-se em ambos os casos a domicílio familiar, e poderá abranger valores mobiliários, cuja renda será aplicada na conservação do imóvel e no sustento da família. 
porque não se refere aos bens "acessórios" (móveis, utensílios etc.) tradicionalmente vinculados ao bem principal (imóvel residencial) que o instituto visa proteger, mas a outra categoria de bens, também "principais" (por exemplo, ações, quotas em fundos de investimentos etc.). A "destinação" desse segundo tipo de bens, completamente nova dentro do instituto jurídico em estudo, bem demonstra a sua autonomia, guindando-o à condição de objeto principal da proteção familiar, ao lado do bem de família tradicionalmente concebido. Fazendo notar o traço protetivo da família enquanto instituição de interesse do Estado, a parte final do Artigo 1.712 trouxe para dentro do "bem de família" um bem que não é destinado à residência familiar, nem é acessório deste.

Para além da "moradia", agora também o "sustento" da família passou a ser objeto central da proteção conferida pelo Código Civil. Os valores mobiliários de que trata o referido dispositivo legal podem ser instituídos como bem de família e, assim, tornados impenhoráveis, a fim de garantirem o sustento familiar (bem como a conservação do outro bem central do instituto jurídico, a residência).
Todavia, para evitar abusos e a má-fé, a limitação dos valores mobiliários agora admitidos no âmbito da proteção contra a penhora por dívidas resta expressamente prevista no Artigo 1.713, não podendo exceder o valor "do prédio" instituído em bem de família, à época de sua instituição. Significa dizer que os valores dos dois tipos de bens deverão guardar simetria. $\mathrm{O}$ segundo tipo (valores mobiliários) deverá ter seu valor, no máximo, igual ao do primeiro (imóvel), e ambos deverão, no todo, representar, no máximo, um terço do patrimônio líquido existente ao tempo da instituição.

Outro aspecto interessante é que embora os valores mobiliários sejam também bens principais para $o$ instituto jurídico previsto no Código Civil de 2002, porque, como visto, possuem destinação própria (propiciar o "sustento" da família), ${ }^{19}$ a verdade é que a sua instituição dependerá da instituição do bem de família clássico (imóvel para residência familiar).

Talvez 'no futuro, arriscamos dizer, o próximo passo da legislação será no sentido de tornar autônomo o bem de família para o "sustento", independentemente do bem de família para "moradia". Significará

19 Embora também possam servir para a conservação do imóvel de "moradia" da família. 
a proteção de bens (imóveis, móveis ou valores) destinados apenas à manutenção da família (alimentação, saúde, educação, lazer etc.), com apoio na própria Constituição da República, em face dos direitos sociais por ela conferidos, ou seja, independentemente da família possuir um imóvel próprio para residência protegido contra a penhora de dívidas. Sem dúvida, a porta está aberta para mais esse passo na evolução do instituto jurídico em análise.

Por certo que o Código Civil de 2002, no que tange ao bem de família clássico, está se referindo a um único imóvel, que deve servir para residência da família. A Lei não se refere a imóveis, mesmo que dois, ou mais, caibam na fração do patrimônio líquido permitida, qual seja, um terço, valendo-se o diploma legal do substantivo no singular, mantendo a tradição do instituto jurídico nesse ponto. Disso decorre a impossibilidade de dois ou mais imóveis serem instituídos como bens de família, seja para a moradia, seja para a conservação da moradia, ou para o sustento da família. A expressão encartada no caput do Artigo 1.711, ao estabelecer um percentual sobre o acervo patrimonial do instituidor, não pode conduzir a equívoco. O percentual limita o valor total dos bens que forem instituídos, sim, mas apenas um deles pode ser imóvel, e ainda deverá ser destinado à moradia familiar. $\mathrm{Na}$ presença deste, então, outros bens poderão ser instituídos, mas não imóveis, e ainda, por efeito, para finalidades diversas (conservação do imóvel instituído e/ ou sustento da família).

Ainda sobre os "valores mobiliários", o Artigo 1.718, com objetivo de resguardar ainda mais ferreamente o patrimônio familiar, prevê que qualquer forma de liquidação da entidade que os administrar, não os atingirá, devendo ser transferidos por ordem judicial a outra instituição semelhante.

De acordo com DINIZ ${ }^{20}$, sem evitar o óbvio, "pelo Artigo 1.712, in fine, do Código Civil, a renda dos valores imobiliários abrangidos pelo bem de família deverá ser aplicada para conservar o imóvel, que abriga os instituidores e sua prole, e para sustentar a família". Esses valores imobiliários deverão ser obrigatoriamente individualizados no instrumento de constituição do bem de família, ao contrário das 
pertenças e acessórios, que não serão necessariamente especificados.

A forma de constituição do bem de família, tratada no Artigo 1.714 do Código Civil, estabelece que a mesma se dá mediante o registro do título no Registro de Imóveis e, para perfeita compreensão desse aspecto, veja-se a Lei ${ }^{\circ} 6.015$, de 31.12.1973 (Artigo. 167, I, 1 c/c Artigo 260 a 265). Não demasiado lembrar que o Artigo 1.711, ao tratar dos títulos pelos quais o instituidor poderá lançar sua disposição de vontade, inovou, em relação ao testamento. No entanto, para tornar coerente o Artigo 1.711, o Artigo 1.714 deverá ser interpretado de forma a dar legitimidade para a instituição do bem de família não apenas aos cônjuges e aos terceiros, mas também aos companheiros e aos demais integrantes da entidade familiar.

Outro requisito para a instituição do bem de familia voluntário é a solvibilidade do instituidor ao tempo da instituição, o que não significa a inexistência de dívida anterior à constituição, como se depreende da análise dos artigos 70 e 71 do Código Civil de 1016 e do artigo 1.715, do $\mathrm{CC} / 2002$.

Para o artigo 1.716, a isenção da impenhorabilidade do bem de família, de que trata o artigo 1.715, durará enquanto viver um dos cônjuges, ou, na falta deste, até que os filhos completem a maioridade. A doutrina critica esse artigo por tratar-se de uma reedição do Artigo 70 do Código Civil de 1916, pois apresenta idêntico defeito, à medida que deveria incluir, além dos cônjuges, os conviventes e os instituidores integrantes da entidade familiar.

Nesse sentido, RITONDO ${ }^{21}$ esclarece que "cabe, por fim observar que, tendo em vista a compreensão extensiva do significado entidade familiar, extinguindo-se o bem de família por falecimento de ambos os cônjuges, ou ambos os companheiros, e restando apenas filho ou filhos maiores e capazes, estes e aquele poderão reconstituir o bem de família por intermédio de uma nova escritura pública e um novo registro, desde que preenchidos os requisitos exigidos em lei, incorrendo apenas numa pequena descontinuidade do beneficio".

$\mathrm{O}$ princípio constitucional da igualdade entre os cônjuges para a administração do bem de família vem expresso no Artigo 1.720, todavia, se entre eles não houver concordância caberá ao juiz decidir. $\mathrm{O}$ dispositivo legal deixou de citar os companheiros, que deveriam estar nele contemplados por força do Artigo 
226, parágrafo $3^{\circ}$, da Constituição da República ${ }^{22}$, questão que caberá à jurisprudência solver.

No Artigo 1.721, parágrafo único, dispõe que se a dissolução da união ocorrer por morte de um dos componentes do casal e o imóvel for o único por eles titulados, o sobrevivente poderá pedir a extinção do bem de família. No entanto, a extinção não é automática, devendo ser requerida ao juiz competente. Ocorre que o bem de família voluntário, quando instituído por ambos os cônjuges, ou companheiros, decorre da vontade comum de proteger a família, e não simplesmente o casal. A morte de um dos instituidores não faz fenecer a vontade que gerou a instituição do bem de família. A literalidade na interpretação do indigitado dispositivo legal pode conduzir à traição da vontade criadora da proteção familiar no caso concreto. Quando o ato de disposição competir a ambos os cônjuges, havendo filhos o casal, não poderá, por uma questão lógica, em caso de falecimento de um dos cônjuges ou companheiros, ficarem os filhos desprotegidos em face da possibilidade do cônjuge/ companheiro sobrevivente postular judicialmente a extinção do bem de família com fulcro no parágrafo único do Artigo 1.721. Essa conclusão encontra apoio, por analogia, no que dispõe o Art. 20 do Decreto-Lei $\mathrm{n}^{\circ} 3.200 / 41$, e no Artigo 1.722 do Código Civil, o qual estabelece que o bem de família se extingue com a morte "de ambos os cônjuges e com a maioridade dos filhos", o que, obviamente, também se aplicando à união estável.

\section{A LEI No 8.009/90 E SUA APLICAÇÃO EM FACE DO ORDENAMENTO JURÍDICO ATUAL}

Feitas as considerações a respeito da disciplina do Bem de família no Código Civil de 2002, passa-se à análise da Lei $\mathrm{n}^{\circ}$ 8.009/1990, que trata da impenhorabilidade do imóvel próprio que serve à residência da família, e de outros bens acessórios, como equipamentos e móveis quitados que guarnecem o prédio. Como já assinalado, atualmente o bem de família é disciplinado por essas duas leis; na primeira, está presente o instituto jurídico do bem de família que a doutrina convencionou chamar de bem de família voluntário, que depende da vontade privada e do respeito à forma para sua constituição válida. Na segunda, temse o bem de família legal, que, para 
a sua existência, validade e eficácia, dispensa escritura pública e a vontade privada sob qualquer aspecto. Tratase de uma modalidade imposta verticalmente pelo Estado, para a proteção de um dos inalienáveis valores sociais da família, o direito à moradia, na concretização do princípio fundamental da dignidade humana, encartado na Constituição da República. Nesse sentido, é a lição de MARMITT.23

Dispõe o caput do artigo $1^{\circ}$ da Lei 8.009/1990, que o imóvel residencial próprio do casal, ou da entidade familiar, é impenhorável e não responderá por qualquer tipo de dívida civil, comercial, fiscal, previdenciária ou de outra natureza, contraída pelos cônjuges ou pelos pais ou filhos que sejam seus proprietários e nele residam, salvo nas hipóteses previstas nesta lei. $\mathrm{O}$ parágrafo único do mesmo artigo estabelece que a impenhorabilidade compreende o imóvel sobre o qual se assentam a construção, as plantações, as benfeitorias de qualquer natureza e todos os equipamentos, inclusive os de uso profissional, ou móveis que guarnecem a casa, desde que quitados. Sendo assim, a primeira questão que se põe em discussão é quanto a palavra casal descrita no caput do Artigo $1^{\circ}$, cujo conceito deve ser estendido para abranger o par formado pelos companheiros, considerando que a Constituição da República, promulgada apenas dois anos antes, em seu Artigo 226, parágrafo $3^{\circ}$, os igualou para efeitos de proteção por parte do Estado. Em relação à entidade familiar, vide a mesma disposição constitucional, a qual se alinha o parágrafo quarto do mesmo artigo, que estendeu o conceito de entidade familiar à

23 MARMITT, Arnaldo. Bem de família. Rio de Janeiro: Aide. 1995, p. 21: “A nova lei implantou em nosso direito a impenhorabilidade coativa, sem reduzir a disponibilidade do proprietário, sem nada alterar em relação a ele, inobstante ter dado maior amplitude ao instituto do bem de família. Embora dispense a vontade do instituidor, não o despoja da livre disposição, por não impor a inalienabilidade da coisa. Sobrepôs, assim, o superior interesse da família a todos os demais interesses humanos, vez que a penhora de móveis e imóveis que se usufruem em comum, dentro do agrupamento familiar, em composse e em união de proveito, priva todos da utilidade, interferindo na esfera jurídica de todos. Quem não é parte passiva na execução por ela não pode ser afetado, a ponto de não mais poder se beneficiar de tais bens. A instituição do beneficio ex lege dispensa a escritura pública, vez que é impositiva, sendo também irrelevante a circunstância de o beneficiário ser ou não devedor". 
comunidade formada por "qualquer dos pais e seus descendentes".

Em nível infraconstitucional, a Lei $\mathrm{n}^{\circ}$ 8.009, de 29.03.1990, em sintonia com, àquela época novel, Constituição da República, acolheu a expressão, guardando fidelidade ao seu estreito sentido. Note-se que o seu Artigo $1^{\circ}$ faz referência ao "casal" e às dívidas contraídas pelos "cônjuges", bem como à "entidade familiar" e as dívidas contraídas pelos "pais ou filhos". O Código Civil de 2002 bem poderia ter contribuído para a evolução do instituto neste ponto, mas, tomado por uma timidez anacrônica, o legislador não o fez, valendo-se exclusivamente dos termos "cônjuges", "instituidor", "filhos" e "interessados", sem em momento algum falar em "companheiros" entre os Artigos 1.711 e 1.722 .

$O$ benefício legal alcança $o$ imóvel dos casais, homem e mulher, legalmente casados, bem como os ligados através da união estável, sendo que o domínio no primeiro caso pode ser pertencente a ambos os cônjuges ou apenas um deles, ou, no caso de entidade familiar, pertencente a membro único ou a um conjunto de membros em condomínio, desde que residentes no imóvel, na condição de proprietários ou promitentescompradores. Nesse sentido, é o entendimento da doutrina ${ }^{24} \mathrm{e}^{25}$ :

Requisito indispensável para que se caracterize o bem de família previsto na Lei 8.009/1990, além da propriedade, é a efetiva residencia do casal ou da entidade familiar no bem. Porém, como toda regra no direito comporta exceção, ela não deve ser interpretada de maneira absoluta, sob pena de prejudicar a finalidade do instituto. Nesse sentido, a jurisprudência tem acolhido o

24 RITONDO, op. cit., p.67: "Cumpre salientar, no entanto, que a indispensabilidade da propriedade do bem de família por parte do casal ou da entidade familiar deve ser mitigada para incluir o caso resida em um imóvel sobre o qual possua direito proveniente de contrato de compromisso de compra e venda quitado ou de escritura definitiva ou não registrada, por exemplo. Nesse sentido, reforça a afirmativa acima o fato de que o direito à adjudicação compulsória independe do registro do compromisso de compra e venda no cartório de imóveis, conforme esclarece Súmula $n^{\circ} 239$ do Superior Tribunal de Justiça."

25 MARMITT, op. cit., p.60: "Referindo-se a imóvel residencial próprio da entidade familiar, a Lei 8.009/1990 não deixou de abranger a posse da família sobre o bem que lhe serve de residência. Ora, a lei visa salvaguardar a moradia da família, não importando por óbvio se o imóvel que concretiza a moradia é de propriedade da família. Esta interpretação, aliás, somente reforça os propósitos eminentemente sociais da própria da lei." 
entendimento conforme os acórdãos abaixo colacionados. ${ }^{26}$

Em verdade, para efeito das suas disposições, a Lei $n^{\circ} 8.009 / 90$ não concebeu o bem de família visando a proteção do "sustento" da família, senão, apenas, para a sua "moradia".

A proteção para o "sustento" só aportou na legislação com o Artigo 1.712 do Código Civil de 2002. Entretanto, como se depreende dos julgados citados, em especial do REsp 159.213/ES (Rel. Min. Sálvio de Figueiredo, DJ 21.06.99), publicado antes da entrada em vigor do atual Código Civil, tal noção já havia sido incorporada à cultura jurídica pátria, e adotada como fundamento de decidir pelos Tribunais.

A impenhorabilidade em estudo bem de família legal -estende-se ao imóvel de qualquer valor, já que não há limitação na lei, o que em muito se aparta da impenhorabilidade alusiva ao bem de família voluntário, que deverá estar contido dentro da fração de um terço do patrimônio líquido do instituidor. ${ }^{27}$

No que tange ao disposto no Artigo $2^{\circ}$ da Lei 8.009/1990, que exclui da impenhorabilidade os veículos de transporte, obras de arte e adornos suntuosos, trata-se de exceção à regra. Sobre o tema, veja-se o entendimento

26 (1) “..., em hipóteses que tais, a renda proveniente do aluguel pode ser utilizada para a subsistência da família ou mesmo para o pagamento de dívidas (cf. REsp 462.011/PB, da relatoria deste Magistrado, DJ 02.02.2004) (Resp.445/.990/MG, Segunda Turma, Rel. Min. Franciulli Netto, julgado em 09/11/04)

(2) "Dentro de uma interpretação teleológica e valorativa, calcada inclusive na teoria tridimensional do Direito-fato, valor e norma (Miguel Reale), faz jus aos benefícios da Lei $8.009 / 90$ o devedor que, mesmo não residindo no único imóvel que lhe pertence, utiliza o valor obtido com a locação desse bem como complemento da renda familiar, considerando que o objetivo da norma foi observado, a saber, o de garantir a moradia familiar ou a subsistência da família" (REsp 159.213/ES, Rel. Min. Sálvio de Figueiredo, DJ 21.06.99)

(3) “...Uma interpretação sistêmica, e não literal, da Lei $n^{\circ}$ 8.009/90 leva a concluir que esta é apenas uma das características, dentre um conjunto de outras, que indica a situação de imprescindibilidade do imóvel à própria sobrevivência da unidade familiar, de modo que a sua locação não lhe afasta tal condição, desde que se comprove que tal procedimento seja levado a efeito em benefício da própria sobrevivência a família". Precedentes do STJ. 2. ( Resp.550387/SE, Primeira Turma, Min. Luiz Fux. Julgado em $16 / 10 / 03)$.

27 “... A sentença guerreada bem soube diferenciar bens impenhoráveis daqueles que não o são. Isso porque a impenhorabilidade dos móveis que guarnecem a residência 
de GONÇALVES. $^{28} \mathrm{O}$ parágrafo único do referido dispositivo legal traz a impenhorabilidade que se estende aos bens móveis quitados que guarneçam o imóvel no qual reside o devedor na condição de locatário e que sejam de sua propriedade. Por óbvio, ainda que a lei não preveja, seus benefícios se estendem aos bens móveis que guarnecem a casa do comodatário que reside, com sua família, em imóvel emprestado. ${ }^{29}$
Relevante para o tema é a análise a respeito de dois incisos do Artigo $3^{\circ}$ da dita Lei: o inciso IV, que trata da cobrança de impostos, predial ou territorial, taxas e contribuições devidas em função do imóvel familiar, e inciso VII, que se ocupa da obrigação decorrente de fiança concedida em contrato de locação. Justifica o estudo desses dois incisos a sua notória repercussão no meio jurídico. Primeiro, quanto ao inciso IV, este

do devedor, nos termos da Lei n. 8.009/90, por constituir exceção à regra da responsabilidade patrimonial, há que ser entendida restritivamente, mormente em sede de Juizado Especial Cível, sob pena de inviabilizar a satisfação do direito material do credor. 3. Isso resulta em impenhorabilidade apenas dos bens essenciais à dignidade $\mathrm{e}$ funcionalidade do lar, caso em que se enquadram geladeira, televisor e lava-roupas, mas não antena parabólica..." (Recurso Cível n ${ }^{\circ} 71002867265$, Primeira Turma Recursal Cível, Turmas Recursais, Relator: Leandro Raul Klippel, Julgado em 23/11/2010)

Disponível em : <http://www1.tjrs.jus.br/busca/?q=bens+moveis+impenhorabilidade $\& \mathrm{tb}=$ jurisnova\&pesq $=$ ementario \&partialfields $=\% 28 \mathrm{TipoDecisao} \% 3 \mathrm{Aac} \% 25 \mathrm{C} 3 \% 25 \mathrm{~B}$ $3 \mathrm{rd} \% 25 \mathrm{C} 3 \% 25 \mathrm{~A} 3 \mathrm{o} \% 7 \mathrm{CTipoDecisao} \% 3 \mathrm{Amonocr} \% 25 \mathrm{C} 3 \% 25 \mathrm{~A} 1$ tica\%29\&requiredfie lds=\&as_q=\&ini=30>. Acesso em: 07.11.11.

28 GONÇALVES, Carlos. Impenhorabilidade do bem de família: Lei 8.009/1990, desfazimento das penhoras, arrematações e adjudicações anteriores, embargos de terceiro. Porto Alegre: Síntese. 1998, p.191: "Melhor seria se em vez de "veículos de transporte" usasse a expressão "veículo particular de transporte de passageiros de uso não profissional" porque, assim, estariam desde logo, excluídos os veículos de transporte de cargas e de passageiros de uso profissional (táxi e ônibus) e outros utilizados para o desempenho de qualquer ofício ou profissão, inclusive motocicletas, bicicletas e carroças, etc. Ademais, o Artigo 649, inciso VI, do CPC já previa a ressalva quanto à impenhorabilidade dos livros, máquinas, utensílios e instrumentos necessários ou úteis ao exercício de qualquer profissão, onde quer que se encontrem. No que tange a adornos suntuosos, a conceituação do que sejam é bastante subjetiva, de sorte que tal classificação ficaria a critério do oficial de justiça."

29 GONÇALVES, Idem, p.191. 
exclui a impenhorabilidade do bem de família legal quando a execução for referente a tributos devidos em função do imóvel familiar e contribuições a ele relativas: Imposto sobre Propriedade Predial Territorial e Urbana (IPTU), Imposto sobre a Propriedade Territorial Rural (ITR), Imposto sobre Serviço (ISS) e contribuição previdenciária arrecadada pelo INSS, ambos no caso da construção civil; e taxas decorrentes do poder de polícia, incidentes sobre o imóvel..$^{30}$ Incluem-se também nesta as despesas condominiais, por terem como fato gerador a manutenção do imóvel. É entendimento há muito consolidado na doutrina que tais despesas devem ser consideradas para excepcionar a impenhorabilidade do bem de família, em virtude de suas características, com o que não diverge a jurisprudência. ${ }^{31}$
Por força do Artigo 82 da Lei $n^{\circ} 8.245 / 1991$, da Lei de Locações, foi incluído no Artigo $3^{\circ}$, da Lei $8.009 / 1990$, o inciso VII, excetuando a impenhorabilidade por obrigação decorrente de fiança concedida em contrato de locação. RITONDO faz uma crítica contra o respectivo inciso, que estaria em contradição com "várias garantias do direito à moradia, restringindo-lhe os efeitos quanto ao fiador de relação locatícia, em verdadeira oposição ao mandamento constitucional que exige uma atitude negativa do legislador e do estado, no sentido de não se poder legislar ou atuar contraditoriamente às determinações constitucionais de proteção a esse direito fundamental. $O$ inciso em exame constitui um retrocesso, visto que revoga a norma que qualifica o único imóvel do

30 RITONDO, op. cit., p.81.

31 (1) “...II - O vocábulo "contribuição" a que alude o inciso IV, Artigo $3^{\circ}$ da Lei $n^{\circ}$ $8.009 / 90$ não se reveste de qualquer conotação fiscal, mas representa, in casu, a quota parte de cada condômino no rateio das despesas condominiais. Nesta circunstância, a obrigação devida em decorrência da má conservação do imóvel da recorrente há de ser incluída na ressalva do mencionado dispositivo... STJ.Resp.1199.801/RJ,Terceira Turma, Rel. Min. Waldemar Zveiter, julgado em 16/05/2000).

(2) "PENHORA - BEM DE FAMILIA. Contribuições Condominiais - Artigo $3^{\circ}$, inciso IV, da Lei 8.009/1900 - Precedentes. I. Consolida-se nesta Corte entendimento jurisprudencial no sentido de que passível de penhora o imóvel residencial da família, quando a execução se referir a contribuições condominiais sobre ele incidentes. Precedentes da Quarta Turma: Resp. 160.710-SP. II. Recurso não conhecido (Terceira Turma, Resp.152-512-SP, Rel. Min. Valdemar Sveiter, julgado em 03/02/1999). 
fiador, no qual reside com sua família impenhorável". ${ }^{32,33}$

Portanto, quanto a essa exceção de impenhorabilidade, divergem tanto doutrina quanto jurisprudência em relação à sua suposta inconstitucionalidade. A doutrina, quase que de forma pacífica, da qual é exemplo GONÇALVES $^{34}$, que entende ser esta previsão inconstitucional por violar a isonomia (Artigo $5^{\circ}$, caput, da CF/88) e a proteção da dignidade humana (Artigo $1^{\circ}$, III). Primeiro, porque o devedor principal (locatário) não pode ter o seu bem de família penhorado, enquanto o fiador (em regra devedor subsidiário - Artigo 827 do CC) pode suportar a constrição. A lesão à isonomia reside no fato da fiança ser contrato acessório, que não pode trazer mais obrigações do que o contrato principal (locação). Em reforço, haveria desrespeito à proteção constitucional da moradia (Artigo $6^{\circ}$ ), uma das exteriorizações do princípio de proteção da dignidade da pessoa humana. De fato, em relação a esse inciso da Lei 8.009/1990, muitas são as discussões e divergências travadas em doutrina e em jurisprudência. $\mathrm{Na}$ primeira predominam os que defendem a inconstitucionalidade da norma, diante da sua afronta ao direito constitucional de moradia, ao passo que na segunda impera entendimento diverso, no sentido de não reconhecer a inconstitucionalidade. No bojo dessa discussão, RITONDO ${ }^{35}$ aponta algumas soluções a fim de não haver o sacrifício do direito constitucional à moradia do fiador.

32 RITONDO, op. cit., p.88.

33 MARMITT, op.cit., p. 95, oferecendo o seu contributo, acrescenta: "Ocorre, assim, uma proteção excessiva do locatário em detrimento do fiador. Assegurase a intangibilidade dos móveis quitados que guarnecem na moradia alugada, e não se isenta de penhora os mesmos bens do fiador e da sua família. Impossibilita-se, ainda, o exercício do direito regressivo do fiador contra seu afiançado, cujo bem de família e acessórios não garantem créditos ao fiador. Assim procedendo, o legislador injustiçou o cidadão que presta um grande serviço ao outro, um benefício ou favor, sem contraprestação nenhuma".

34 GONÇALVES, op. cit, p.194 a 195.

35 RITONDO, op. cit., p.94: "De fato, seria, no mínimo, pouco criativo afirmar que a única solução para esse problema é o sacrifício do direito à moradia do fiador, juntamente com a desconsideração do princípio da isonomia, uma vez que já existe a alternativa de se ampliar o seguro-fiança locatício, apesar de haver resistência por parte das seguradoras em massificar esse tipo de cobertura. Além dessa, novas soluções podem ser desenvolvidas pelo mercado e fomentadas pelo Poder Público.” 
O $4^{\circ}$ Artigo $^{36}$ acrescenta mais uma hipótese para o afastamento da impenhorabilidade do bem de família legal. Pode se observar que o principal elemento formador do impedimento ao benefício é a má-fé do devedor, pois sabendo da sua insolvência e tendo a consciência da ilicitude do ato, transfere a residência familiar para imóvel mais valioso, com o intuito de fraudar seus credores. Entretanto, conforme explica GONÇALVES ${ }^{37}$, "é condição sine qua non que seja presente a má-fé, a intenção preconcebida de lesar e locupletar-se o devedor, sacrificando os credores ao tornar impenhorável a nova casa de moradia pela simples ocupação como residência". Configurada a má-fé, o credor poderá recorrer ao Judiciário pela via da ação Pauliana, para anular o ato de alienação ou desfazer transferência indevida da impenhorabilidade do imóvel.

O parágrafo segundo do Artigo $4^{\circ}$ da Lei $\mathrm{n}^{\circ} \quad 8.009 / 90$ trata da impenhorabilidade do imóvel rural que serve à residência, enquanto 0 inciso XXVI do Artigo $5^{\circ}$ da Constituição da República, cuida da impenhorabilidade rural em relação à dívidas decorrentes da sua atividade produtiva $^{38}$. São, portanto, casos diversos de impenhorabilidade do imóvel rural.

Quando a entidade familiar possuir vários imóveis, utilizando-os como residências, a impenhorabilidade

36 Art. $4^{\circ}$ - Não se beneficiará do disposto nesta lei aquele que, sabendo-se insolvente, adquire de má-fé imóvel mais valioso para transferir a residência familiar, desfazendose ou não da moradia antiga.

$\S 1^{\circ}$ Neste caso, poderá o juiz, na respectiva ação do credor, transferir a impenhorabilidade para a moradia familiar anterior, ou anular-lhe a venda, liberando a mais valiosa para execução ou concurso, conforme a hipótese.

37 GONÇALVES, op. cit., p.195.

38 Art. $5^{\circ}$ - inciso XXVI: "a pequena propriedade rural, assim definida em lei, desde que trabalhada pela família, não será objeto de penhora para pagamento de débitos decorrentes de sua atividade produtiva, dispondo a lei sobre os meios de financiar o seu desenvolvimento".

Lei $n^{\circ} 8.009$, Art. $4^{\circ}, \S 2^{\circ}$ : "Quando a residência familiar constituir-se em imóvel rural, a impenhorabilidade restringir-se-á à sede de moradia, com os respectivos bens móveis, e, nos casos do art. $5^{\circ}$, inciso XXVI, da Constituição, à área limitada como pequena propriedade rural." 
legal terá de recair sobre aquele de menor valor, por força do Art. $5^{\circ}$ da Lei $n^{\circ} 8.009 / 90$, a não ser que ocorra a instituição do bem de família voluntário, na forma do Código Civil atual, respeitada a limitação do valor.

Da análise conjunta da Lei 8.009/1990 e do Código Civil de 2002, observa-se que cada diploma legal possui características distintas, além é claro de suas semelhanças. Já se viu no curso deste estudo que aquela lei regra o bem de família legal, instituto jurídico de direito público e, em princípio, irrenunciável, em virtude de emanar da própria Constituição da República para a proteção da moradia, do lar. O Código Civil de 2002, por seu turno, disciplina o bem de família voluntário, de direito material. ${ }^{39}$

Do cotejo de ambas as leis exsurge em primeiro plano a questão alusiva à coexistência e à possibilidade de concomitância dos dois tipos de bem de família.

Há quem defenda que a preexistência da instituição do bem de família voluntário, seguido do bem de família legal, sobre a mesma propriedade não implica a inutilidade da instituição voluntária. Nesse sentido, Rainer Czajnowski ${ }^{40}$ : "poder-se-á assegurar à família a impenhorabilidade sobre qualquer dos imóveis próprios, mesmo não sendo o de mais baixo valor, e a escolha voluntária prevalecerá, então, sobre a determinação legal". Mas nessa hipótese não se terá a coexistência dos institutos jurídicos, e sim uma sobreposição. Invertendo a cronologia, na hipótese da instituição do bem de famillia voluntário Código Civil de 2002, portanto, quando já em vigência o bem de família legal - Lei 8.009\1990, este cederá espaço, mas voltará a ter efeito em caso de desconstituição daquele. Inteligência do Artigo 1.711, caput, do Código Civil de 2002, que ressalva a manutenção das regras de impenhorabilidade da Lei 8.009\90.

Sendo assim, ambas as leis são admitidas e coexistem enquanto previsões hipotéticas e abstratamente consideradas, mas sua aplicação

39 De acordo com MARMITT, op. cit, p.18 e 19, “a inalienabilidade voluntária do bem de família é denominada de pro tempore, onde o proprietário tem a faculdade de usar e dispor do bem, sem riscos de perdê-lo e ser dele despojado".

40 MARMITT, apud, RAINER, Czajkwonski, $A$ impenhorabilidade do bem de familia, p.32. 
concreta, de forma concomitante, se mostra impossível. ${ }^{41}$ Se o objetivo do Estado é a proteção da residência familiar e, considerando que o mínimo necessário para garantir o direito fundamental à moradia pode ser alcançado com um imóvel apenas, não se poderá admitir, jamais, sob pena de se chancelar a fraude e o abuso, que dois imóveis possam se tornar impenhoráveis para a mesma finalidade.

Enquanto o bem de família legal é irrenunciável, o bem de familia voluntário pode ser objeto de modificação e até de extinção por força da mesma vontade criadora. De acordo com o Artigo 1.717 in fine, o imóvel instituído como bem de família não pode ser alienado sem o consentimento dos interessados e seus representantes, ouvido o Ministério.
Sendo assim, a contrario sensu, mediante o consentimento exigido pela lei, poderá sê-lo. ${ }^{42}$

A última pontual diferença entre os dois tipos de bens de família reside em torno da limitação de valor imposta ao bem de família voluntário, limitação esta que não é prevista na versão legal do instituto, uma vez que o Artigo $1^{\circ}$, paragrafo único da Lei $8.009 \backslash 90$, não traz nenhuma limitação de valor para o bem de família.

\section{PRINCIPAIS TEMAS CONTROVERTIDOS EM JURISPRUDÊNCIA}

Postos os esclarecimentos necessários para a compreensão do bem de família e suas disposições

41 MARMITT, apud Jurisprudência Brasileira, 170-21- DONALDO AMELIM.: "no reconhecimento de uma situação de vantagem prevista no parágrafo único do Artigo $5^{\circ}$ da Lei $\mathrm{n}^{\circ} 8.009 \backslash 90$, para a hipótese, de existindo vários imóveis utilizados como residência, subsistir impenhorável, aquele já declarado bem de família, ainda que o valor maior que os demais, excepcionando a regra no sentido de tal impenhorabilidade incidir nesse caso, relativamente àquele imóvel de menor valor".

42 DINIZ, Maria Helena, op. cit, p.1117: "Sendo certo assim que, caso o marido resolva vendê-lo, deverá obter anuência de sua mulher e de seus filhos, que consentirão, por curador especial, designado pelo juiz, ouvindo-se ainda o órgão do Ministério Público. A cláusula somente poderá ser levantada por mandado do juiz se for requerido pelo instituidor que o justifique por motivo relevante e comprovado, ou por qualquer interessado, que prove desvio em sua destinação. Se na família houver menores impúberes, não poderá ser eliminada a cláusula de alienação do imóvel, salvo se houver sub-rogação em outro imóvel para a habitação da família, desde que razoavelmente justificada. Contudo, como já se observou, essa inalienabilidade será relativa, por subsistir apenas enquanto viverem os consortes e até que os filhos atinjam a maioridade". 
nas legislações vigentes, passa-se a análise dos três temas específicos de maior repercussão na jurisprudência atual.

$\mathrm{O}$ primeiro diz respeito à impenhorabilidade do imóvel destinado à moradia dos novos tipos de entidades familiares e de pessoas que vivam sozinhas, circunstâncias não previstas legalmente e que colocam em xeque o benefício do instituto.

Até algum tempo, o que se entendia por entidade familiar era apenas o agrupamento formado pelos pais ou filhos. ${ }^{43}$ Note-se que a Lei $\mathrm{n}^{\circ} 8.009 / 90$ não diz pais " $e$ " filhos, mas pais "ou" filhos, noção que foi reproduzida no Código Civil de 2002, como se depreende do "parágrafo único" do Artigo 1.720. Porém, em tempos atuais, em que são constantes as mudanças no estado civil das pessoas, bem como suas preferências sexuais, e também a opção, ou a circunstância, de se viver sozinho, coube à jurisprudência abrandar o rigor legal no trato do instituto em questão.

Antes de outro comentário, é forçoso reconhecer a impossibilidade de a pessoa que viva sozinha se autobeneficiar com a instituição do bem de família voluntário, com assento no Código Civil. Entretanto, poderá, por interpretação jurisprudencial, como se verá adiante, beneficiar-se do instituto do bem de família legal (Lei $\left.{ }^{\circ} 8.009 / 90\right)$. Nesse sentido, a bem colocada conceituação de entidade familiar, do Ministro Humberto Gomes de Barros. ${ }^{44}$

43 Art. $1^{\circ}$ da Lei $n^{\circ} 8.009 / 1990$.

44 "Esse dispositivo formou-se na linha de interpretação ampliativa que o Superior Tribunal de Justiça desenvolve sobre Artigo $1^{\circ}$ acima transcrito. Como registra o eminente Ministro Relator, nossa jurisprudência declara sob o abrigo da impenhorabilidade, a residência:

a) da viúva, sem filhos (REsp. 276.004/Menezes Direito);

b) de pessoa separada judicialmente (REsp 218.377/Barros Monteiro);

c) irmãos solteiros (REsp 57.606/Alencar).

Esses três exemplos, lembrados pelo Ministro Relator, indicam a percepção de que o legislador, ao utilizar a expressão "entidade familiar" não se referiu à família coletiva, mas àqueles entes que a integram (irmãos solteiros) ou dela são remanescentes (viúva ou divorciado).

De fato, não teria sentido livrar de penhora a residência do casal e submeter a essa constrição a casa, onde um dos integrantes do casal continua a morar, após o falecimento de seu cônjuge. 
Com acerto a percepção predominante em nossos Tribunais a respeito da ampliação do conceito de entidade familiar. Com sensibilidade, o judiciário apanhou o fato humano em algo que lhe é bem caro, a solidariedade. Não raro, ocorre de alguém, depois de longos e felizes anos de convivência no seio familiar, assistir ao passamento dos seus familiares, restando o último de sua estirpe. Seria incongruente, para não dizer desumano, proteger tal pessoa, no que toca à sua moradia, apenas enquanto existisse sua família. Desintegrado o grupo familiar; a família só resta nas lembranças, nos porta-retratos, na imaterialidade da saudade, e decididamente seria injusto e cruel tributar o infortúnio da solidão com a sobretaxa do desamparo legal, que, há de se convir, soaria até discriminatório.

Portanto, consagrada a interpretação extensiva da entidade familiar, salvaguardando $\mathrm{o}$ direito à moradia a outras tantas pessoas, o Superior Tribunal de Justiça, valendo-se, como precedentes, dos Recursos Especiais $\mathrm{n}^{\circ} \mathrm{s}$ 139.012, 450.989 , 57.606 e 159.851, sintetizou o seu entendimento na forma da Súmula $\mathrm{n}^{\circ}$ 364: "O conceito de impenhorabilidade de bem de familia abrange também o imóvel pertencente a pessoas solteiras, separadas e viúvas". ${ }^{45}$

Em suma, o sistema jurídico pátrio põe a salvo da penhora por dívidas o prédio destinado à residência de

A interpretação teleológica do Artigo $1^{\circ}$ revela que a norma não se limita ao resguardo da família. Seu escopo definitivo é a proteção de um direito fundamental da pessoa humana: o direito à moradia. Se assim ocorre, não faz sentido proteger quem vive em grupo e abandonar o indivíduo que sofre o mais doloroso dos sentimentos: a solidão".

(Resp. 450-989-RJ, Rel. Min.Humberto Gomes de Barros, julgado em 07\06\2004)

Disponível em: $<\mathrm{https} / /$ ww2.stj.jus.br/revistaeletronica/Abre_Documento.asp?sLink= ATC\&sSeq $=1202311 \&$ sReg $=200200951187 \&$ sData $=20040607 \&$ sTipo $=5 \&$ formato $=$ PDF $>$. Acesso em: 14/01/11.

45 Seguem, à guisa de exemplos, os seguintes julgados:

“CIVIL. BEM DE FAMÍLIA. Ação de reparação de danos proposta contra réu solteiro. Matrimônio superveniente, antes da execução da sentença de procedência, cuja penhora recaiu sobre imóvel em que o casal residia. Bem de família que se reconhece, porque à época do gravame o imóvel era impenhorável por força de lei. Recurso especial conhecido e provido" (Resp. 139.012. Rel. Min. Ari Pargendler - Terceira Turma. Julgado em 05/08/02).

"PROCESSUAL - EXECUÇÃO - IMPENHORABILIDADE - IMÓVEL RESIDÊNCIA - DEVEDOR SOLTEIRO E SOLITÁRIO - LEI 8.009/90. 
outros tipos de entidades familiares, bem como da pessoa que nele habita sozinha, como consequência do direito social à moradia, materializando o princípio fundamental da dignidade da pessoa humana, previsto na Constituição da República. ${ }^{46}$

É em atenção a esse princípio fundamental que se deve proteger de forma especial a moradia enquanto direito social, não sendo razoável admitir, sob pena de injustificável discriminação, o desamparo de determinados grupos familiares ou de pessoas que, por alguma razão, que não cabe ao legislador investigar, se encontram vivendo sozinhas.

Cabe apenas registrar que, comungando o mesmo entendimento de BUZANAR, não se mostra correta a construção do conceito de "família unipessoal" como um tipo de família, para que seja possível garantir à pessoa humana que viva sozinha a proteção prevista para o bem "de família". Ora veja-se, uma pessoa sozinha não perfaz um casal e não configura uma família, porquanto, conceito de família é sociológico, e não jurídico; então, para que haja uma família, exige-se, no mínimo, duas pessoas. ${ }^{47} \mathrm{O}$ artifício que conduz ao conceito de familia unipessoal esbarra na lógica, sem contar com o respaldo de qualquer outro ramo do conhecimento. De família não se trata, o que não implica concluir que a pessoa que viva sozinha não mereça o amparo do instituto jurídico em estudo. Apenas não é

- A interpretação teleológica do Artigo $1^{\circ}$, da Lei $8.009 / 90$, revela que a norma não se limita ao resguardo da família. Seu escopo definitivo é a proteção de um direito fundamental da pessoa humana: o direito à moradia. Se assim ocorre, não faz sentido proteger quem vive em grupo e abandonar o indivíduo que sofre o mais doloroso dos sentimentos: a solidão - É impenhorável, por efeito do preceito contido no Artigo $1^{\circ}$ da Lei 8.009/90, o imóvel em que reside, sozinho, o devedor celibatário. "(REsp 450.989SP, Corte Especial, DJ de 07/04/2003)

Disponível em: $<$ https://ww2.stj.jus.br/revistaeletronica/Abre_Documento.asp?sLink= ATC\&sSeq $=1202311 \&$ sReg $=200200951187 \&$ sData $=20040607 \&$ sTipo $=5 \&$ formato $=$ PDF>. Acesso em: 14.01.11.

46 BUNAZAR, Maurício; op. cit.; p. 415: "É tempo de repensar o instituto e sua denominação, porque o sistema constitucional pátrio garante o direito de moradia à pessoa humana independentemente de viver ou não em família, afinal não haveria sentido em deixar sem proteção alguém só pelo fato de ser só. $O$ instituto que estabelece a impenhorabilidade da moradia, tenha o nome que tiver, deve proteger a pessoa humana, viva em grupo familiar, viva isoladamente."

47 BUNAZAR, Maurício; op. cit.; p. 415. 
família. Poder-se-ia com isso cogitar que resta superada a denominação do instituto em exame, visto que abrangendo outras hipóteses, além da família, de "bem de família" já não seria, exclusivamente. Nesse sentido, BUZANAR que, embora não sugerindo outra denominação, preconiza a superação daquela atualmente em uso. No entanto, o abandono da denominação tradicional nos parece desnecessário, ao menos até aqui, não tendo uma exceção a dimensão necessária para impor a modificação da expressão que denomina a regra geral. É verdade que $o$ instituto em estudo vem sofrendo modificações importantes, vem alargando suas hipóteses de incidências, objetiva e subjetivamente, e talvez em um futuro próximo seja aconselhável rever sua denominação, porém não nesse estágio de sua evolução. Para a família é que ele se volta, sendo a pessoa que viva só apenas uma exceção.

O segundo tema relevante enfrentado em jurisprudência reside na divergência quanto à validade do oferecimento do bem de família à penhora pelo próprio devedor, que, assim, abriria mão da proteção à moradia familiar. Esse tema traz à baila a análise do direito (ou falta dele) do proprietário dispor do imóvel com base na autonomia privada da vontade. Nesse caso, em jurisprudência, se fala em "bem de família ofertado".

Imagine-se $o$ caso em que um devedor, executado, ofereça o próprio Bem de Família, imóvel de sua residência e de seus familiares, à penhora. Estaria ele, sem dúvida alguma, no exercício da autonomia privada da sua vontade, renunciando à impenhorabilidade do bem de família em favor do credor. Mas seria realmente dado ao devedor o exercício de tal faculdade? $\mathrm{O}$ direito conferido pelo Estado na forma da Lei ${ }^{\circ} 8.009 / 90$ seria renunciável?

Há quem sustente que a proteção constante da Lei 8.009/90, em situações excepcionais, seria passível de renúncia, pois estaria na parte disponível dos direitos pessoais e, nesse sentido, já há entendimento do Superior Tribunal de Justiça. ${ }^{48}$

Todavia, com o mais elevado respeito, não há como concordar

48 “CIVIL. BEM DE FAMÍLIA. LEI No 8.009, DE 1990. A impenhorabilidade resultante do Artigo $1^{\circ}$ da Lei $\mathrm{n}^{\circ} 8.009$, de 1990, pode ser objeto de renúncia válida em situações excepcionais; prevalência do princípio da boa-fé objetiva. Recurso especial não conhecido" (Resp n ${ }^{\circ} 554.622 / R S$, Relator Ministro Ari Pargendler, DJ de 01/02/2006, 527).

Disponível em: https://ww2.stj.jus.br/revistaeletronica/Abre_Documento.asp?sLink $=$ ATC $\&$ sSeq $=2203372 \& s R e g=200300849110 \& s D a t a=20060201 \&$ sTipo $=5 \&$ formato $=\mathrm{P}>$. Acesso em: 14.01.11. 
tal posicionamento, porquanto, a premissa basilar para a tese contrária é de que o Bem de Família Legal envolve um direito social fundamental, calcado em um principio constitucional fundamental: o direito à moradia e a dignidade da pessoa humana. A partir dessa ideia, decorrem todos os contraargumentos à autonomia privada do devedor de dispor do bem de família.

A conclusão de que a renúncia ao Bem de Família Legal é inadmissível, e de que a autonomia privada por parte do devedor não é capaz de gerar efeitos válidos, é um entendimento que se impõe pela própria lógica do instituto jurídico em estudo, à medida que a conduta do renunciante constitui o exercício de um direito nefasto à entidade familiar, em confronto com a clara intenção da Lei $\mathrm{n}^{\mathrm{o}} 8.009 / 90 \mathrm{e}$, de forma mais drástica, da própria Constituição da República, e nesse sentido também há julgados do Superior Tribunal de Justiça que advogam favoravelmente. ${ }^{49,50}$

No direito português, CARDOSO, citando o entendimento

49 PROCESSUAL CIVIL E TRIBUTÁRIO. EXECUÇÃO FISCAL. BEM DE FAMÍLIA OFERECIDO À PENHORA. RENÚNCIA AO BENEFÍCIO ASSEGURADO PELA LEI 8.009/90. IMPOSSIBILIDADE.

1. A indicação do bem de família à penhora não implica renúncia ao benefício conferido pela Lei 8.009/90, máxime por tratar-se de norma cogente que contém princípio de ordem pública, consoante a jurisprudência assente neste STJ.

2. Destarte, a indicação do bem à penhora não produz efeito capaz de elidir o benefício assegurado pela Lei 8.009/90. Precedentes: REsp 684.587/TO, Relator Ministro ALDIR PASSARINHO JUNIOR, Quarta Turma, DJ de 13 de março de 2005; REsp 242.175/ PR, Relator Ministro RUY ROSADO DE AGUIAR, Quarta Turma, DJ de 08 de maio de 2.000; REsp 205.040/SP, Relator Ministro EDUARDO RIBEIRO, Terceira Turma, DJ de 15 de abril de 1999).

3. As exceções à impenhorabilidade devem decorrer de expressa previsão legal.

4. Agravo Regimental provido para dar provimento ao Recurso Especial (Min. Relator Francisco Falcão. Agr. Resp. no 813.546, julgado em 10/04/07).

Disponível em: $<$ https://ww2.stj.jus.br/revistaeletronica/Abre_Documento.asp?sLink= ATC\&sSeq $=3122656 \&$ sReg $=200600192188 \& s D a t a=20070604 \&$ sTipo $=5 \&$ formato $=$ PDF>. Acesso em: 14.01.11

50 PROCESSUAL CIVIL. EXECUÇÃO. EMBARGOS. BEM DE FAMÍLIA. IMÓVEL INABITADO DEVIDO A DESMORONAMENTO PARCIAL. ÚNICO BEM. RENÚNCIA INCABÍVEL. PROTEÇÃO LEGAL. NORMA DE ORDEM PÚBLICA. LEI N. 8.009/90. 
de Pinto Furtado, faz alusão à possibilidade de penhora sobre o bem de família, se o cônjuge do executado deu o seu assentimento no processo à nomeação feita por este $^{51}$. A noção apresentada remete à concepção de um instituto jurídico cuja proteção tem um caráter mais patrimonial (bens) do que social (família), algo que não se afina com a linha adotada pelo ordenamento jurídico brasileiro, que se estrutura a partir da Constituição da República, que possui outra inspiração, conforme já apontado.
O terceiro tema controvertido, aqui reputado como relevante, e um dos mais polêmicos, está na divergência, em doutrina e em jurisprudência, acerca da penhora do bem de família do fiador de locação, previsto como exceção de impenhorabilidade na Lei $8.009 / 90$ (Artigo $3^{\circ}$, inciso VII, inserido pela Lei de Locações $n^{0}$ 8.245/91). Em curta síntese, em doutrina e em jurisprudência a divergência diz respeito à constitucionalidade ou à inconstitucionalidade do precitado dispositivo legal.

I. A proteção legal conferida ao bem de família pela Lei n. $8.009 / 90$ não pode ser afastada por renúncia ao privilégio pela devedora, constituindo princípio de ordem pública, prevalente sobre a vontade manifestada, que se tem por viciada ex vi legis.

II. A circunstância de achar-se desocupado o bem, após parcial desmoronamento, não constitui motivo à descaracterização do bem de família, sob pena de se agravar a situação de infortúnio experimentada pela executada, que, segundo a prova colhida, mora "de favor na casa dos pais".

III. Recurso especial conhecido e provido, para afastar a constrição incidente sobre o imóvel (MINISTRO ALDIR PASSARINHO JUNIOR, relator, RECURSO ESPECIAL $\mathrm{N}^{\mathrm{o}} 684.587$ - TO, julgado em 18.11.04).

Disponível em: $<\mathrm{https} / / \mathrm{ww} 2$. stj.jus.br/revistaeletronica/Abre_Documento.asp?sLink= ATC \&sSeq $=1515583 \& \mathrm{sReg}=200401158692 \& \mathrm{sData}=20050314 \& \mathrm{sTipo}=5 \&$ formato $=$ PDF>. Acesso em: 14.01 .11

51 CARDOSO, Augusto Lopes. Da Responsabilidade dos Cônjuges por Dívidas Comerciais. Temas de Direito de Família. Coimbra: Livraria Almedina. 1986, p. 204/205: "Não servirá também de argumento que o próprio executado poderia ter nomeado bens comuns certos, pois que se nos afigura que, se o Tribunal tiver conhecimento, pelo modo como for feita a nomeação, que os bens têm aquela natureza, deverá opor-se pelo mesmo modo, pois que está em causa uma disposição que se destina, não directamente, a proteger o executado, mas o patrimônio familiar, de que ele é apenas um dos titulares. O mesmo não se acontecerá, evidentemente, se o cônjuge do executado deu o seu assentimento no processo à nomeação que o outro fez." 
Em doutrina defende-se a inconstitucionalidade da exceção de impenhorabilidade prevista no Artigo $3^{\circ}$, inciso VII, da Lei 8.009/90, uma vez que ele afronta os princípios e as garantias previstos na Constituição da República: o direito à moradia (previsto noArtigo $6^{\circ}$, com sua redação dada pela Emenda Constitucional $n^{\circ} 26 / 2000$ ). É preciso dizer que esse entendimento também encontra eco em parcela da jurisprudência, como se extrai, à guisa de exemplo, do julgamento monocrático do Ministro Carlos Mário Velloso, no RE 352.940-4/SP (decisão julgada em 25/04/2005). ${ }^{52}$

Entretanto, esse posiciona-mento foi alterado no julgamento do Recurso Extraordinário $\mathrm{n}^{\circ}$ 407.688-SP, tendo

52 "A Lei 8.009 , de 1990 , Artigo $1^{\circ}$, estabelece a impenhorabilidade do imóvel residencial do casal ou da entidade familiar e determina que não responde o referido imóvel por qualquer tipo de dívida, salvo nas hipóteses previstas na mesma lei, Artigo $3^{\circ}$, inciso I a VI. Acontece que a Lei 8.245, de 18.10.91, acrescentou o inciso VII, a ressalvar a penhora "por obrigação decorrente de fiança concedida em contrato de locação.' É dizer, o bem de família de um fiador em contrato de locação teria sido excluído da impenhorabilidade. Acontece que o Artigo $6^{\circ}$ da C.F., com a redação da EC $\mathrm{n}^{\circ} 26$, de 2000, ficou assim redigido: “Artigo $6^{\circ}$. São direitos sociais a educação, a saúde, o trabalho, a moradia, a segurança a previdência social, a proteção à maternidade e à infância, a assistência aos desamparados, na forma desta Constituição. $O$ bem de família, a moradia do homem e sua família justifica a existência de sua impenhorabilidade: Lei $8.009 / 90$, Artigo $1^{\circ}$. Essa impenhorabilidade decorre de constituir a moradia um direito fundamental. Posto isso, veja-se a contradição: a Lei 8.245, de 1991, excepcionando o bem de família do fiador, sujeitou o seu imóvel residencial, imóvel residencial próprio do casal, ou da entidade familiar à penhora. Não há dúvida que a ressalva trazida pela Lei 8.245, de 1991, no inciso VII do Artigo $3^{\circ}$ feriu de morte o princípio isonômico, tratando desigualmente situações iguais, esquecendo-se do velho brocardo latino: $u b i$ eadem ratio, ibi eadem legis dispositivo, ou em vernáculo: onde existe a mesma razão fundamental, prevalece a mesma regra de Direito. Isto quer dizer que, tendo em vista o princípio isonômico, o citado dispositivo, inciso VII do Artigo $3^{\circ}$, acrescentado pela Lei 8.245/91, não foi recebido pela EC 26, de 2000. Essa não recepção mais se acentua diante do fato de a EC 26, de 2000, ter estampado, expressamente, no Artigo $6^{\circ}$, C.F., o direito à moradia como direito fundamental de $2^{a}$ geração, direito social. Ora, o bem de família da Lei $8.009 / 90$, Artigo $1^{\circ}$, encontra justificativa, foi dito linha atrás, no constituir o direito à moradia um direito fundamental que deve ser protegido e por isso mesmo encontra garantia na Constituição. Em síntese, o inciso VII do Artigo $3^{\circ}$ da Lei 8.009, de 1990, introduzido pela Lei 8.245, de 1991, não foi recebido pela C.F., Artigo $6^{\circ}$, redação da EC 26/2000."

Disponível em: $<$ https://ww2.stj.jus.br/revistaeletronica/Abre_Documento.asp?sLink= ATC\&sSeq $=2055780 \&$ sReg $=200400289480 \& s D a t a=20051128 \& s$ Tipo $=3 \&$ formato $=$ PDF>. Acesso em: 10.01.11. 
como Relator o Min. Cezar Peluso, que argumentou no sentido de que não há conflito entre a Lei 8.009/1990 e a Constituição. ${ }^{53}$ De certo que, se prevalecesse $o$ entendimento contrário, haveria um desequilíbrio no mercado imobiliário.

Como se vê, o inciso VII do Artigo $3^{\circ}$ da lei $8.009 / 90$ vem gerando divergências, tanto em doutrina quanto em jurisprudência. No precitado julgamento ${ }^{54}$, manifestaram-se contrariamente os ministros Eros Grau, Carlos Ayres Britto e Celso de Mello, proferindo votos no sentido da inconstitucionalidade do inciso em exame. Os votos divergentes no julgamento foram no sentido de que a Constituição ampara a família e a sua moradia e que essa proteção consta do artigo $6^{\circ}$ da Constituição da República, de forma que tal direito, porque fundamental, tornaria indisponível o bem de família para a penhora. No entanto, como já salientado, prevaleceu o entendimento do eminente Ministro Relator. Por 7 votos a 3, o plenário acompanhou o voto do ministro Cezar Peluso e, assim, mantendo a decisão proferida pelo Tribunal de Alçada do Estado de São Paulo, que determinou a penhora do bem de família do fiador. $\mathrm{O}$ acórdão foi publicado em outubro de $2006 .{ }^{55}$

Não obstante essa decisão do Supremo Tribunal Federal, o tema ainda vem rendendo discussões e divergências jurisprudenciais, do que são

53 “EMENTA: Fiador. Locação. Ação de despejo. Sentença de procedência. Execução. Responsabilidade solidária pelos débitos do afiançado. Penhora de seu imóvel residencial. Bem de família. Admissibilidade. Inexistência de afronta ao direito de moradia, previsto no Artigo $6^{\circ}$ da CF. Constitucionalidade do Artigo $3^{\circ}$, inc. VII, da Lei ${ }^{\circ} 8.009 / 90$, com a redação da Lei $n^{\circ} 8.245 / 91$. Recurso extraordinário desprovido. Votos vencidos. A penhorabilidade do bem de família do fiador do contrato de locação, objeto do Artigo $3^{\circ}$, inc. VII, da Lei ${ }^{\circ} 8.009$, de 23 de março de 1990, com a redação da Lei $n^{\circ} 8.245$, de 15 de outubro de 1991 , não ofende o Artigo $6^{\circ}$ da Constituição da República (RE 407688, Relator(a): Min. CEZAR PELUSO, Tribunal Pleno, julgado em 08/02/2006).

Disponível em: $<\mathrm{http}: / /$ redir.stf.jus.br/paginador/paginador.jsp?docTP=AC\&docID=261768> . Acesso em: 17.01.11.

54 Idem.

55 Disponível em: $<$ http://redir.stf.jus.br/paginador/paginador.jsp?docTP=AC\&docID= 261768>. Acesso em: 17.01.11. 
exemplos os julgados cujas ementas vão transcritas neste estudo. A linha jurisprudencial que perfilha o entendimento sobre a penhorabilidade do bem de família, em face da renúncia do interessado/proprietário, reconhece a preponderância do princípio da autonomia da vontade privada, no exercício do poder de dispor do imóvel (constitucionalidade do inciso VII, Artigo $3^{\circ}$, da Lei 8.009/90). ${ }^{56}$

Mas também há que sustente em sentido diametralmente oposto, defendendo a impenhorabilidade, com base na inconstitucionalidade do indigitado dispositivo legal. ${ }^{57}$

56 (1) STF. AI N. 584436/ RJ - Rel. Min. Cesar Peluso, julgado em 03/02/09).

(2) “...se foi indicado à penhora pelo próprio devedor, cônjuge da embargante, em acordo homologado. Renúncia a eventual direito... (TJRS. Apel. n. 70022628614, julgado em 26/05/08).

(3) ... Não se decreta a nulidade de negócio jurídico, firmado à luz do artigo 104, do CC, por meio do qual a embargante, expressamente, renunciou à impenhorabilidade de seu bem de família, dado em garantia ao pagamento de dívida contraída por seu marido. Embora se reconheça a proteção conferida à família pela Constituição da República, em seu artigo 226, exteriorizada, dentre outras formas, pela garantia do direito à moradia, regulada pela Lei $n^{\circ} 8.009 / 90$, não se pode admitir tamanha intervenção do Estado na vontade, livremente manifestada, do particular, o que equivaleria a dizer que os cidadãos não têm condições de gerir a sua própria pessoa e bens, culminando com a violação de um outro direito individual, constitucionalmente assegurado, que é o da propriedade (artigo $5^{\circ}$, XXII). (TJMG. Apel. no 1.0079.05.196849-7/001. Julgado em 04/06/08).

(4) ...Possibilidade de que a constrição recaia sobre bem imóvel de quem presta fiança locatícia, mesmo que não possua outros da mesma natureza e lhe sirva de moradia. Incidência do Artigo $3^{\circ}$, inciso VII, da Lei $n^{\circ} 8.009 / 90$, com a alteração procedida pelo Artigo 82 da Lei $n^{\circ} 8.245 / 91$. Precedentes desta Corte, do STJ e do STF (Agravo de Instrumento $\mathrm{N}^{\mathrm{o}} 70040127870,16^{\mathrm{a}}$ Câmara Cível, TJRS, julgado em 21/12/2010).

57 (1) ...A proteção legal conferida ao bem de família pela Lei n. 8.009/90 não pode ser afastada por renúncia ao privilégio pelo devedor, constituindo princípio de ordem pública, prevalente sobre a vontade manifestada, que se tem por viciada ex vi legis. (STJ. Resp. n. 805-713, Rel. Min. Aldir Passarinho Junior. Julgado em 15/03/05).

(2) ...A Lei $\mathrm{n}^{0} 8.009 / 90$ disciplina hipóteses de impenhorabilidade absoluta, com normas de caráter público, impositivo, constituindo direito irrenunciável... Portanto, em virtude da natureza jurídica desse diploma legal, ainda que o executado ofereça o bem à penhora, tal ato não pode ser considerado como renúncia ao direito previsto na lei em questão, para especial proteção dos membros da entidade familiar que utilizam o imóvel para moradia, podendo inclusive o próprio devedor embargar para alegar a nulidade da constrição (TJMG. Apel n.1.0261.04.030180-4/001(1), Rel. Des. Dárcio Lopardi Mendes. Julgado em 06/09/07). 
$\mathrm{O}$ quarto e último tema de relevância enfoca especificamente a possibilidade de penhora da única residência da pessoa hipossuficiente por dívida de tributos incidentes sobre o respectivo bem, em face da exceção prevista no Artigo $3^{\circ}$, inciso IV, da Lei $n^{\circ} 8.009 / 90$.

Nota-se aqui a combinação de outros temas polêmicos: a impenhorabilidade do bem que serve à residência de pessoa que mora sozinha, agravada com a particularidade da hipossuficiência; e a discussão que cerca a constitucionalidade das exceções previstas na Lei $n^{\circ} 8.009 / 90$, no seu Artigo $3^{\circ}$.

MELLO DOS SANTOS ${ }^{58}$, em interessante trabalho, procura demonstrar a existência de uma colisão entre aquela exceção legal (Artigo $3^{\circ}$, inciso IV) e as normas constitucionais que estabelecem o respeito à função social da propriedade imobiliária urbana e $\mathrm{o}$ direito à moradia. Dito autor defende o que denomina de "uma real aplicação" das disposições constitucionais no caso específico, sob pena de ocorrer uma crise no reconhecimento $\mathrm{e}$ na identidade daquelas garantias constitucionais. Nesse caminho, argumenta que o direito à moradia é vinculado às necessidades básicas do ser humano (classificado como um direito da personalidade), e que o mesmo já poderia ser reconhecido a partir do princípio da função social da propriedade, previsto constitucionalmente, à medida que o proprietário, ao utilizar seu imóvel para moradia, está destinando o seu imóvel ao exercício dessa função. Por fim, conclui no sentido de que o direito fundamental social à moradia pode ter a efetividade pretendida, impedindo qualquer tipo de constrição legal, sem encontrar obstáculos, "na medida em que serve de fundamento para a declaração de inconstitucionalidade ou ilegalidade (no caso do direito fundamental já estar concretizado por meio de legislação ordinária) de todo e qualquer ato legislativo, administrativo ou mesmo privado que ofenda o seu conteúdo mínimo." Ou seja, seria possível "exigir do legislador e do intérprete que não adotem comportamentos no sentido de subverter o sentido dessa norma."

Tal entendimento representa posição minoritária na doutrina, e

58 MELLO DOS SANTOS, Wagner: “A Impenhorabilidade do Imóvel Residencial da Pessoa Hipossuficiente por Dívida de Tributos: Proteção ao Direito à Moradia e Aplicação da Justiça Social Tributária." Disponível em: <http://www.uff.br/ppgsd/ dissertacoes/wagner_mello.doc> Acesso em: 25.01. 2011. 
com ela não podemos concordar. As decisões judiciais que admitem a penhora do único bem da pessoa por dívida de IPTU, mesmo que hipossuficientes, com fundamento na exceção prevista na Lei $\mathrm{n}^{\mathbf{o}}$ $8.009 / 90$, não é inconstitucional, ao contrário do que preconiza MELLO DOS SANTOS, pois não impede a implementação e a realização dos direitos fundamentais previstos na Constituição da República. A discordância dessa parcela da doutrina assenta-se no argumento de que as decisões judiciais prestigiam demasiadamente o Artigo $3^{\circ}$ da precitada lei, sem considerar uma interpretação mais ampla, bem como os dispositivos constitucionais que determinam $o$ respeito à função social da propriedade e ao direito à moradia, que, segundo MELLO DOS SANTOS $^{59}$, vêm sendo mantidos sem aplicabilidade e efetividade.

$\mathrm{Na}$ ausência de posicionamento específico do Supremo Tribunal Federal e do Superior Tribunal de Justiça, resta analisar o que vem sendo entendido em jurisprudência perante os tribunais da Federação, a respeito da exceção prevista no inciso IV do Artigo $3^{\circ}$, considerando a interpretação pretoriana em relação ao inciso VII (fiança locatícia).
Segundo MELLO DOS SANTOS ${ }^{60}$ citando o resultado do julgamento do Recurso Extraordinário $\mathrm{n}^{\circ} 407699$, "a possibilidade de penhora do único bem da pessoa por dívida de fiança em contratos locatícios indica, em tese, uma disposição de afastar princípios de justiça social (como, por exemplo, a função social da propriedade e/ ou moradia) em prol do princípio da autonomia da vontade".

Fosse prevalecer o entendimento que torna a impenhorabilidade do bem de família algo absolutamente inatingível, bastaria promulgar uma lei com artigo único, com expressa observação de que não comporta exceções. Porém, tamanho reducionismo contrasta com a complexidade da realidade social. Os conteúdos dos princípios fundamentais não podem ser completados ao sabor das conveniências, de inclinações políticas e ideológicas, que se movem e se transformam com o tempo. É a lei ordinária, sim, instrumento de complemento e de concretização dos princípios fundamentais. Dizer que o direito à moradia não encontra obstáculos, sob pena de ser negada a Constituição, poderia legitimar toda e qualquer invasão à propriedade privada por qualquer pessoa que não possua residência própria. Ou seja, o homem

59 MELLO DOS SANTOS, Wagner; op. cit.

60 Idem. 
sério e probo, que paga o seu aluguel todos os meses, seria um tolo. Se o direito à moradia pode ter a extensão pretendida pela parte da doutrina que preconiza a inconstitucionalidade do inciso IV do Art. $3^{\circ}$ da Lei 8.009/90, entendendo não caber nenhuma restrição ou exceção ao sagrado direito de morar, então, qual seria o limite para essa interpretação? Pior fica, quando se pretende relegar o Direito Civil a uma condição menor, no processo de individualização do direito ao caso concreto. ${ }^{61}$ Com toda a certeza, o Direito Civil codificado é um obstáculo às interpretações livres a respeito dos preceitos constitucionais. Sem ele, a jurisprudência estaria absolutamente livre para preencher os conteúdos dos princípios constitucionais, porta que também estaria aberta àqueles que determinam as políticas públicas do País. Olvidam, porém, que a nossa tradição não é herdeira do sistema da common law.
Por tudo isso, não se pode aceitar $o$ argumento de MELLO DOS SANTOS ${ }^{62}$, de que "o Estado somente poderia retirar o imóvel quando implementasse políticas públicas capazes de garantir o acesso ao direito à moradia daquele indivíduo inadimplente com tributos incidentes sobre o respectivo bem", até porque tal argumento não resiste à conclusão, que o próprio autor refere em outra passagem de seu trabalho, de que "um direito social que pode ser desenvolvido e implementado de diversas maneiras, por meio de inúmeras políticas públicas, como por exemplo, o aluguel social, mutirões, alojamentos, financiamento de imóveis, dentre outras experiências". Ora! Se o objetivo de proteção à moradia pode ser alcançado por outros meios, bastando vontade política para tanto, não há razão para sacrificar outros interesses, que também importam para a organização e prosperidade econômica do País.

61 Ibidem: "Ademais, alguns doutrinadores não ousaram suscitar maior aplicabilidade aos dispositivos constitucionais comentados, isso porque a interpretação era realizada (e ainda é, como veremos no caso concreto analisado) com fundamento, em regra, no Código Civil ou em leis esparsas e não na Constituição Federal. Essa afirmação acima pode ser corroborada através da observação feita por Gustavo Tepedino, em texto escrito antes da promulgação do Novo Código Civil, onde ressalta que "os civilistas brasileiros, ainda hoje, reservam à norma ordinária o papel central no processo interpretativo. A prioridade e a imprescindibilidade da norma ordinária na aplicação da Constituição são proposições que se revelam mais que inquietantes: a primeira subverte a hierarquia do sistema, incorrendo no frequente erro de ler a Constituição à luz do código, ao invés de ler o código à luz da Constituição; a segunda, herança da concepção tradicional, não deveria ser hoje considerada mais do que um mero preconceito".

62 MELLO DOS SANTOS, Wagner, op. cit. 


\section{CONCLUSÕES}

Analisada a evolução histórica do bem de família, flagra-se que a sua concepção original, no Código Civil de 1916, foi bastante modificada até os dias atuais, de tal modo que coexistem dois tipos desse instituto jurídico: o bem de família legal, previsto na Lei $\mathrm{n}^{\circ} 8.009 / 90$, que decorre de uma imposição do Estado, e o bem de família voluntário, com lugar no Código Civil de 2002, que pode ser instituído com base na autonomia da vontade privada. Certo é, no entanto, que ambos os tipos de bem de família atualmente vigentes servem para uma proteção bem maior que aquela prevista originalmente. Agora, não apenas as famílias, mas também as entidades familiares e até as pessoas solteiras estão protegidas. Outro alargamento do instituto jurídico em estudo está na inovação trazida com o Código Civil de 2002, estendendo a proteção para além da moradia, para abranger também o sustento da família e da entidade familiar.

A Constituição da República teve papel fundamental na evolução do instituto jurídico em comento, à medida que, em seu Artigo 226, propiciou grandes avanços, ampliando o conceito das entidades familiares. Trouxe, também, as cláusulas de igualdade entre os cônjuges, o reconhecimento da união estável e o direito fundamental da moradia (Artigo $6^{\circ}$ ), incluído como direito fundamental pela Emenda Constitucional $\mathrm{n}^{\circ} 26$, de 2000, se tornou um dos princípios norteadores do instituto bem de família, muito embora tardiamente, por ser posterior à Lei 8.009/90.

O legislador tem se sensibilizado com os percalços econômicos enfrentados pela família brasileira, uma vez que várias são as adaptações implantadas no instituto do bem de família, ao passo que a jurisprudência vem exercendo um papel fundamental para a concretização do instituto jurídico, em razão das controvérsias que lhe chegam, carentes de pacificação.

Cumpre destacar uma forte inclinação à limitação da autonomia privada, tão cara ao Direito Civil, pela tutela constitucional da moradia. O que se pode observar dos julgados transcritos no curso deste trabalho é a tendência desse direito fundamental se sobrepor ainda mais ao direito de propriedade. A limitação imposta ao devedor quanto à renúncia ao bem de família legal, em favor do pagamento de dividas, e, ainda, a divergência travada quanto à inconstitucionalidade do inciso VII do Artigo $3^{\circ}$ da Lei $n^{\circ} 8.009 / 90$, demonstram que o instituto do bem de família vem paulatinamente se sobrepondo aos aspectos eminentemente patrimoniais. 


\section{BIBLIOGRAFIA}

AZEVEDO, Álvaro Vilaça. Bem de Família. 2. ed. São Paulo: Editora Revista dos Tribunais. 1984.

BUNAZAR, Maurício. $O$ Duplo Tratamento Legal do Bem de Família e Suas Repercussões Práticas. Direito de Família e das Sucessões / coordenação Gisela Maria Fernandes Novaes Hironaka, Flávio Tartuce, José Fernandes Simão. Rio de Janeiro: Forense; São Paulo: Método, 2009.

CARDOSO, Augusto Lopes. Da Responsabilidade dos Cônjuges por Dividas Comerciais. Temas de Direito de Família. Coimbra: Livraria Almedina. 1986.

DINIZ, Maria Helena. Código Civil Comentado. São Paulo: Saraiva, 2002.

ESPINOLA, Eduardo. Breves Annotações ao Código Civil Brasileiro. Volume Primeiro. Bahia: Joaquim Ribeiro \& Co Editores, 1918.

GONÇALVES, Carlos. Impenhorabilidade do bem de família: lei
8.009/90, desfazimento das penhoras, arrematações e adjudicações anteriores e embargos de terceiro. $4^{\mathrm{a}}$ edição. Porto Alegre: Síntese, 1998.

MARMITT, Arnaldo. Bem de família. Rio de Janeiro: Aide, 1995.

MELLO DOS SANTOS, Wagner: A Impenhorabilidade do Imóvel Residencial da Pessoa Hipossuficiente por Dívida de Tributos: Proteção ao Direito à Moradia e Aplicação da Justiça Social Tributária. Disponível em <http://www.uff.br/ppgsd/ dissertacoes/wagner_mello.doc $>$ Acesso em: 25. 01. 2011.

PARIZATTO, João Roberto. Da Penhora e da Impenhorabilidade de Bens no CPC e na Lei $N^{o}$ 8.009/90. São Paulo: LED Editora de Direito. 1998.

RITONDO, Domingo Pietrangelo. Bem de família. Rio de Janeiro: Elsevier. 2008. 
$\because$ 